Review

\title{
INVESTIGATIONS ON HEALTH CONDITIONS OF CHERNOBYL NUCLEAR POWER PLANT ACCIDENT RECOVERY WORKERS FROM LATVIA IN LATE PERIOD AFTER DISASTER
}

Jeḷena Reste ${ }^{1,3, \#}$, Tija Zvagule ${ }^{1,3}$, Natalja Kurjāne ${ }^{1,3}$, Andrejs Šḳesters $^{2}$, Alīse Silova ${ }^{2}$, Maija Eglīte ${ }^{1,3}$, Jolanta Cîrule $^{3}$, Natālija Gabruševa ${ }^{3}$, Andris Ziverts ${ }^{4}$, and Elvīra Čurbakova ${ }^{3}$

\footnotetext{
${ }^{1}$ Institute of Occupational Safety and Environmental Health, Rīga Stradiṇš University, Dzirciema iela 16, Rĩga, LV-1007, LATVIA jelena.reste@rsu.Iv, tijazv@inbox.Iv, natalja.kurjane@hotmail.com, maija.eglite@rsu.Iv

${ }^{2}$ Laboratory of Biochemistry, Rīga Stradinš University, Dzirciema iela 16, Rīga, LV-1007, LATVIA andrejs.skesters@rsu.Iv, alise.silova@rsu.Iv

${ }^{3}$ Centre of Occupational and Radiological Medicine, Pauls Stradinš Clinical University Hospital, Pilsoṇu iela 13, Rīga, LV-1002, LATVIA arodacentrs@stradini.Iv

${ }^{4}$ State Medical Commission for the Assessment of Health Condition and Working Ability, Ventspils iela 53, Rīga, LV-1002, LATVIA andris.ziverts@vdeavk.gov.Iv

\# Corresponding author
}

Communicated by Modra Murovska

The paper summarises the main findings on Chernobyl Nuclear Power Plant (CNPP) accident recovery workers from Latvia and their health disturbances, which have been studied by the authors during the last two decades. Approximately 6000 persons from Latvia participated in CNPP clean-up works in 1986-1991. During their work period in Chernobyl they were exposed to external as well as to internal irradiation, but since their return to Latvia they were living in a relatively uncontaminated area. Regular careful medical examinations and clinical studies of CNPP clean-up workers have been conducted during the 25 years after disaster, gathering knowledge on radiation late effects. The aim of the present review is to summarise the most important information about Latvian CNPP clean-up worker health revealed by thorough follow-up and research conducted in the period of 25 years after the accident. This paper reviews data of the Latvian State Register of Persons Exposed to Radiation due to CNPP Accident and gives insight in main health effects found by the researchers from the Centre of Occupational and Radiological Medicine (Pauls Stradinš Clinical University Hospital) and Riga Stradinš University in a number of epidemiological, clinical, biochemical, immunological, and physiological studies. Latvian research data on health condition of CNPP clean-up workers in the late period after disaster indicate that ionising radiation might cause premature ageing and severe polymorbidity in humans.

Key words: Chernobyl accident, ionising radiation, health condition, mortality, premature ageing.

\section{INTRODUCTION}

The accident at the Chernobyl Nuclear Power Plant (CNPP), on 26 April 1986, was the largest disaster in the nuclear industry ever seen by the entire world. Consequences of this tragedy can be felt until nowadays. The total amount of radioactive materials 200 times exceeded the radioactivity caused together by explosions in Hiroshima and Nagasaki (Anonymous, 2006b; Yablokov et al., 2009). Consequently, a large area as well as agricultural products and water were polluted. Enormous amounts of radioactive substances were released into the atmosphere (Ginzburg and Reis, 1991). The main released radionuclides were: ${ }^{131} \mathrm{I}$ (disintegration half-life: $\mathrm{T}_{1 / 2}=8$ days), ${ }^{132} \mathrm{Te}\left(\mathrm{T}_{1 / 2}=3,3\right.$ days), ${ }^{89} \mathrm{Sr}\left(\mathrm{T}_{1 / 2}=53\right.$ days $),{ }^{90} \mathrm{Sr}\left(\mathrm{T}_{1 / 2}=28\right.$ years $),{ }^{134} \mathrm{Cs}$ $\left(\mathrm{T}_{1 / 2}=2\right.$ years $),{ }^{137} \mathrm{Cs}\left(\mathrm{T}_{1 / 2}=30\right.$ years $),{ }^{133} \mathrm{Xe}\left(\mathrm{T}_{1 / 2}=5,3\right.$ days), ${ }^{106} \mathrm{Ru}\left(\mathrm{T}_{1 / 2}=368\right.$ days $),{ }^{35} \mathrm{Kr}\left(\mathrm{T}_{1 / 2}=10,6\right.$ years $)$, ${ }^{144} \mathrm{Ce}\left(\mathrm{T}_{1 / 2}=284\right.$ days $),{ }^{241} \mathrm{Pu}\left(\mathrm{T}_{1 / 2}=13\right.$ years $)$, and ${ }^{239} \mathrm{Pu}$ $\left(\mathrm{T}_{1 / 2}=24\right.$ years) (Anonymous, 2000; Yablokov et al., 2009). Therefore, people who settled in close proximity to the nuclear power plant were exposed not only to external ionising radiation, but also to internal radiation from incorporated radionuclides inhaled with air pollution and ingested with food and water (Aleksanin, 2010).

After the accident, the greatest exposure was received by the group of CNPP accident clean-up workers. More than 600000 inhabitants from the former Soviet Union took part 
in the CNPP accident clean-up works from 1986 till 1991 (Anonymous, 2006b; Yablokov et al., 2009), including approximately 6000 people from Latvia. As in the territory of Latvia, unlike Ukraine, Belarus, and Russia, the background radioactivity after the CNPP accident was not increased significantly, we can analyse changes in the health condition of Chernobyl clean-up workers caused by factors related to the exposure received in Chernobyl. These were mainly external irradiation and radionuclides incorporated into the body. Amongst the non-radiation factors, the most significant were psycho-emotional stress, physical overload, and the effect of heavy metals and other chemicals (Viel et al., 1997; Nikiforov, 2002; Zvagule, 2004). CNPP clean-up workers were mainly healthy men - military personnel and civilians of reproductive age. Most of these men were documented as having received ionising radiation exposure. Doses, as they were recorded in the „Military Passport", might not be always accurate (Mironova et al., 1998; Mironova-Ulmane et al., 2001a; 2001b; Nikiforov, 2002). The data on received doses are thought to be falsified (much smaller), thus contributing to the uncertainty in analytical epidemiological studies, in which individual doses have to be estimated. As since more than 25 years have passed since the CNPP accident, now we can analyse the effects of radioactive exposure in the late period.

The Chernobyl accident created a new problem for health professionals in Latvia, since inhabitants of Latvia participated in clean-up works in Chernobyl. Information about the CNPP accident clean-up workers' health condition and diseases in Latvia has been gathered regularly starting with 1987. Since 1994, data have been included in the Latvian State Register of Persons with Occupational Diseases and Persons Exposed to Radiation due to the CNPP Accident maintained by the specialists of the Centre of Occupational and Radiological Medicine (Pauls Stradiňš Clinical University Hospital). On the basis of information collected in the Centre four doctoral theses (Kurjane, 2001; Zvagule, 2004; Reste, 2013; Silova, 2015) and a lot of scientific studies were completed (Bruvere et al., 1995; 2003; Churbakova et al., 1996; 1999; Eglite et al., 1997; 2009; Mironova et al., 1998; Kalnina et al., 2001; 2012; 2013; 2013a; Kumerova et al., 2000; Kurjāne and Sočnevs, 1999; Kurjane et al., 1999; 2000; 2001; Mazarevica et al., 2000; MironovaUlmane et al., 2001; 2001a; Petukhov et al., 2011; Reste et al., 2012; 2014; Skesters et al., 2005; 2006; 2006a; 2006b; 2008; 2010; 2010a; Viel et al., 1997; Zvagule et al., 2002; 2003). Clinical observations and epidemiological studies among Chernobyl recovery workers showed that these persons suffer from a broad spectrum of different kinds of diseases more seriously than in the non-exposed general Latvian population. This creates a need for further research to determine the reasons and mechanisms of progressing health disturbances.

Complex assessment of Chernobyl NPP accident biological consequences in humans exposed to radiation becomes a topical problem nowadays due to the high number of nuclear power plants in the world and increasing probability of radioactive accidents. The relevance of the medical effects of Chernobyl NPP accident is also shown by many international seminars, symposiums, and congresses that take place each year on these issues. The current paper represents an overview of the main radiation-related health effects in Chernobyl accident clean-up workers from Latvia revealed by a number of studies conducted in the Centre of Occupational and Radiological Medicine during the last 25 years.

\section{AGEING AND MORTALITY OF CHERNOBYL NU- CLEAR POWER PLANT CLEAN-UP WORKERS}

Research in the Centre of Occupational and Radiological Medicine of Pauls Stradiňš Clinical University Hospital is presently focused on the exploration of early senescence signs of CNPP clean-up workers and assessment of late effects of ionising radiation low-dose chronic exposure. Studies were conducted on incidence of different groups of diseases in CNPP clean-up workers from Latvia, in comparison with incidence in the general Latvian male population (Zvagule, 2004; Reste et al., 2012; Reste, 2013; 2014). Many immunological and biochemical observations and studies have been conducted in the Centre.

The Chernobyl Nuclear Power Plant clean-up workers from Latvia received certain amounts of radionuclides that were absorbed in their body due to breathing contaminated air, drinking water and eating local food (Yablokov et al., 2009; Nikiforov, 2002). Many of these radionuclides have long disintegration half-life (for example, ${ }^{137} \mathrm{Cs}$ - 30 years). The pathology process created by the incorporated radionuclides, involves all organs and systems of the body, but not to the same extent. It depends on the organotropism of chemical elements, for example, ${ }^{131-135} \mathrm{I}$ accumulates in thyroid, ${ }^{90} \mathrm{Sr},{ }^{140} \mathrm{Ba},{ }^{226} \mathrm{Ra},{ }^{47} \mathrm{Ca}$ and ${ }^{239} \mathrm{Pu}$ - in bones, ${ }^{144} \mathrm{Ce}$ and ${ }^{60} \mathrm{Co}$ - in liver, and ${ }^{134} \mathrm{Cs}$ and ${ }^{137} \mathrm{Cs}$ evenly disperses into the organism - mainly in the lymphatic system, soft tissue, and genitalia (Anonymous, 2001). The radionuclides residing in the body also have a toxic effect on tissue (Anonymous, 2006c).

The clean-up workers have been living in radiologically non-contaminated area since their return from Chernobyl. However, in the case of Chernobyl clean-up workers in the period after exposure, the effects have not been due to small doses of external ionising radiation and stochastic effects, because in addition to the external radiation they also received internal radiation (Ginzburg, 1991; Zvagule et al., 2002). Official documented doses of radiation exposure in Chernobyl are not reliable, because they do not reflect ionising radiation effects from incorporated radionuclides. A documented exposure dose exists only for about $57 \%$ of the clean-up workers (Eglite et al., 2009). The mean radiation dose estimated from data in the Latvian State Register for Persons Exposed to Radiation in Chernobyl was about $128.76 \pm 70.73 \mathrm{mSv}(\min 0.1 \mathrm{mSv}, \max 500 \mathrm{mSv})$ (Eglite et al., 2009; Reste, 2014). Higher doses were received in 1986 mainly by 20-29-year-old men $(n=1231)$, smaller doses were received in 1987 and later by workers with age 
older than 30 years $(\mathrm{n}=1832)$ (Eglite et al., 2009; Reste, 2014). We believe that the real radiation doses may be higher than those documented ones (Mironova et al., 1998; Mironova-Ulmane et al., 2001; 2001a), as radiation exposure effects in tissues and organs can accumulate.

Mean age of clean-up workers from Latvia at time of participation was $31.9 \pm 7.3$ years mostly they had age 20-39 years and were healthy. In 2011, their mean age was already $56.6 \pm 7.3$ years (Reste, 2013; 2014). CNPP clean-up workers become older and suffered from illness more often. Polymorbidity has been typical for this group of people (Nikiforov, 2002). Existence of several disorders at the same time in one person is more frequently observed in CNPP clean-up workers than in the Latvian male population with corresponding age (Zvagule, 2004). Mean number of diseases for one person in CNPP clean-up workers in 1986-1997 gradually increased from 1.3 to 3.2 (Reste, 2013 ; 2014). A significant increase in the mean number of diseases for one person was observed in the period after 1998. Mean number of diseases in 2000-2007 was 9.6-11.0 (Reste, 2013; 2014), which was higher than in the general Latvian male population with corresponding age (Eglite et al., 2009; Zvagule, 2004). One of the reasons for such high morbidity in CNNP clean-up workers may be regular complete health examination in the Centre of Occupational and Radiological Medicine, which would result in more diseases recorded.

Mortality rates for the time period 1999-2009 were recorded in the Latvian State Population Register (Reste, 2013; 2014). In total, 954 of 5906 CNPP clean-up workers died in the period from 1988 to 2010. Mortality of the clean-up workers gradually increased from 0.2 per 1000 in 1988 to 18.6 per 1000 in 2009. Every year since 2003, about $1.3 \%$ of the initial number of all CNPP clean-up workers died. The most frequent age at which CNPP cleanup workers died in 1999-2009 was between 46-57 years, but in total the largest number of clean-up workers died at the age of 50-59 years (Reste, 2013; 2014). In 1999, the most common cause of death was for exogenous reasons, such as traffic accidents, violent accidents, acute intoxications, suicides etc. (42.6\% of all deaths in 1999), followed by cardiovascular (12.8\%) and oncological (12.8\%) diseases (Reste, 2013; 2014). During the last 10 years, the causes of mortality changed. Exogenous reasons of death decreased, and mortality due to cardiovascular diseases has risen dramatically. Mortality due to oncological diseases is growing progressively, but it does not exceed and is even lower than mortality in corresponding general Latvian male population of similar age (Reste, 2013; 2014). These results may be due to regular examination of CNPP clean-up workers, for which the main attention is focused on diagnosis of cancer in early stages. In 2009, in CNPP workers cardiovascular diseases was the main cause of mortality $(43.0 \%$ of all deaths), followed by oncological diseases $(25.3 \%)$ and exogenous reasons $(12.7 \%)$ (Reste, 2013; 2014). These proportions are similar to those in the general Latvian male population. The main disorders among cardiovascular rea- sons of death in CNPP clean-up workers are myocardial infarction, cerebral infarction, cardiomyopathy etc. (Reste, 2013; 2014). Life expectancy at birth for Latvian males in the 2007-2009 period was 65-68 years. In CNPP clean-up workers from Latvia in the time period 1999-2009, mortality was slightly higher in age group 40-54 years than in the general Latvian male population of this age, which might be explained by early ageing (Reste, 2013; 2014; Yablokov et al., 2009; Nikiforov, 2002). In the age group over 55 years, mortality was lower (Reste, 2013; 2014), likely due to regular health observation and lower mean age of the CNPP clean-up workers cohort (mainly not older than 60 years) than that of the general population $>55$ years of age (increase in mortality may be expected after age 60 years).

\section{FUNCTIONAL CONDITION OF CHERNOBYL NPP CLEAN-UP WORKERS}

The study on functional status of CNPP clean-up workers (unpublished data) was conducted in the Centre of Occupational and Radiological Medicine as one of the research directions. The study was conducted in 2010-2011, i.e. 24 years after Chernobyl accident. The study group consisted of 53 CNPP clean-up workers and as control group 47 persons of appropriate age, who were not chronically exposed to ionising radiation. Mean age was $55.5 \pm 7.3$ in the CNPP clean-up worker group and $57.4 \pm 9.4$ years in the control group. The World Health Organisation recommended a questionnaire on disability assessment for health services research (WHO Disability Assessment Schedule II for Health Services Research, 12-Item Self-Administered Version, 2001) which was used for the estimation of functional status. The questionnaire included questions about nonphysical, mental, psychosocial behaviour, and ability. For each person the sum of all answers was calculated (functional ability index - FAI). Participation in the study was on the optional basis. The study was approved by the Regional Committee for Medical Research Ethics.

Mean value of FAI in CNPP clean-up workers was $54.9 \pm$ 8.4 , compared to $60.7 \pm 9.1$ in the control group, and this difference was statistically significant $(p<0.01)$. This indicated a lower functional status in CNPP clean-up workers comparing with control group. A slight negative correlation between FAI and age was observed in the CNPP workers group, while there was no significant correlation observed in control group (unpublished data). This indicated a declining functional status in older CNPP workers, which was not apparent in the control group.

The study revealed major disability in CNPP workers performing tasks such as standing for long time or at least 30 minutes $(73.6 \%$ vs $32.6 \%$ in control group), walking at least $1 \mathrm{~km}$ or equivalent load (49.1\% vs $19.6 \%$ in control group), taking care of household responsibilities (60.4\% vs $41.3 \%$ ), learning a new task (56.6\% vs $34.8 \%)$, and concentrating on doing something for ten minutes $(43.4 \%$ vs $34.8 \%)$. Health problems emotionally affected $88.7 \%$ of CNPP clean-up 
workers, while only $71.7 \%$ of respondents in the control group (unpublished data).

The observed differences between observed groups might be explained by polymorbidity and higher morbidity in CNPP clean-up workers, comparing with the general Latvian population. One of the explanations for poor functional condition of CNPP clean-up workers may be also their premature ageing.

\section{DISABILITY OF CHERNOBYL NPP CLEAN-UP WORKERS}

During the time period of 25 years after the Chernobyl disaster, approximately $85.7 \%$ of the total number of CNPP clean-up workers became disabled (4352 persons) (data of the State Medical Commission for the Assessment of Health Condition and Working Ability; unpublished). The largest part of the disabled CNPP workers lost 25-59\% of working capacity. Most of them are about 40-59 years old. Information from the State Medical Commission for the Assessment of Health Condition and Working Ability indicates that the main reasons of disability of CNPP clean-up workers are:

1) disorders of the nervous system (for example, encephalopathy of mixed origin with psychoorganic syndrome);

2) cardiovascular diseases (complications of arterial hypertension, atherosclerosis, coronary heart disease, cerebrovascular disorders);

3) musculoskeletal and connective tissue disorders.

During the last years, the disability degree progressively worsened due to accompanying ageing related diseases.

\section{HEALTH DISTURBANCES IN CHERNOBYL CLEAN- UP WORKERS}

Clinical observations and examinations of CNPP accident clean-up workers, as well as epidemiological and clinical studies, revealed simultaneous pathologies of many organs characteristic for this group of people (Zvagule, 2004; Eglite et al., 2009; Reste, 2013; 2014). The pathogenesis of these pathologies is very complicated and up to now is not completely clear (Nyagu and Loganovsky, 1996). Our attention was particularly attracted by high and progressively increasing number of the CNPP clean-up workers with diseases of the nervous system as well as the lasting low levels of functional indicators of the immune system. The analysis of morbidity showed changes in the structure of diseases. In 2007, the most frequent diseases affected the nervous system, sense organs of sense and included mental disorders. Morbidity with diseases of the cardiovascular and endocrine systems increased after period 1996-2001, but morbidity with respiratory diseases and disorders of digestive system decreased (Reste, 2013; 2014). The prevalence of nononcological illnesses analysed in 2010 revealed the follow- ing distribution of disorders: diseases of nervous system took the first place - 941 diseases per 1000 CNPP cleanup workers (e.g., encephalopathy - 880 per 1000, non-inflammatory polyneuropathy - 595 per 1000 ), followed by musculoskeletal disorders with 933 cases per 1000 workers (with frequent diffuse pain in bones, specially highlighting cases of osteoporosis among relatively young males - 78 cases per 1000) and mental disorders with 922 cases per 1000 CNPP recovery workers (e.g., cognitive impairment - 454 per 1000 , depression - 35 per 1000). Other diseases included disorders of sense organs (853 per 1000; the most frequent were retinal angiopathy and peripheral retinopathy), disorders of digestive organs (852 per 1000), and cardiovascular diseases (720 per 1000) (Reste, 2013; 2014). The frequency of the diseases of the nervous system for clean-up workers was constantly high. The modern methods of examinations using electroencephalography (EEG) and nuclear magnetic resonance (MR) confirmed brain pathologies (Nikiforov, 2002; Zvagule et al., 2003; Zvagule, 2004). The functional disturbances without changes practically decreased, but the organic pathology increased (Aleksanin, 2010; Holodova et al., 2012).

The clean-up workers with seizures and unconsciousness episodes more often suffer from diseases of nervous systems and sense organs, digestive and circulatory systems, skeleton, muscular and connective tissue systems, as well as with mental disturbances (Zvagule, 2004). It can be stated that these men were more exposed to environmental and occupational factors and should be considered to be more at risk. The stress, overload, psychological, and social problems are more related to those people who were in Chernobyl in 1986 (Viel et al., 1997). It must be pointed out that the energy of radiation had effect on the nervous system elements in stressful conditions (accident itself), and therefore the mental status of clean-up workers during clean-up works was of major importance. As the radiation has an indisputable role in the pathogenesis of some diseases of nervous system and organs of sense (Anonymous, 2006c) the patients from the mentioned group provoke special interest.

In earlier studies it was shown that lead $(\mathrm{Pb})$ levels in blood until 1993-1994 were elevated ( $>40 \mu \mathrm{g} / \mathrm{dl}$ ) for $60-72 \%$ of the clean-up workers (Churbakova et al., 1996; 1999; Kumerova et al., 2000; Zvagule, 2004). In subsequent years the incidence of elevated $\mathrm{Pb}$ level decreased by $6.927 \% \pm 0.329$ per year. The Pb level in blood decreased (correlation coefficient $\mathrm{R}=0.922$; determination coefficient $\left.\mathrm{R}^{2}=0.984\right)$ and in 1998 it did not exceed $40 \mu \mathrm{g} / \mathrm{dl}$ (Zvagule, 2004).

Individual susceptibility to radiation can be very different and certainly is important. Also, the effect of radiation on any biological system can be hidden and can become expressed in the presence of other provoking factors. In the case of clean-up workers, the combined effect of chemical factors (heavy metals etc.) and incorporated radionuclides can be provoked by physical exertion (Nikiforov, 2002). 
Small doses of ionizing radiation cause disturbances in microcirculation (Anonymous 2006b; 2006c; Vlasova-Rozanskaya, 2009). Due to disturbed microcirculation all the organ systems suffer, including the peripheral nervous system. This leads to failure of adaptive capability of the central nervous system (Holodova et al., 2012), leading to mental disorders with cognitive disturbances, depression, and vegetative paroxysms. Biologically active substances caused by exposure to ionising radiation do not primarily cause health effects through the circulatory system, but rather through effects on the vegetative nervous system at the site of their origin (sympathetic and parasympathetic ganglions) (Anonymous, 2006b; 2006c).

\section{ONCOLOGICAL DISEASES IN CHERNOBYL CLEAN- UP WORKERS}

The oncological morbidity of CNPP accident clean-up workers from Latvia has progressively increased (Kurjane et al., 2000; Eglite et al., 2009; Reste et al., 2012). During 1998-2004, there was a notable increase in occurrence of oncological diseases of thyroid gland, prostate and stomach. In 2005-2007, the most important increase in occurrence of oncological diseases of prostate, stomach and lungs was observed in CNPP accident clean-up workers, and it was higher than that among age- and sex-matched groups of the Latvian population (Eglite et al., 2009; Reste et al., 2012; Reste, 2013; 2014). In recent years an increase in number of malignant tumours of urogenital system organs was observed (mainly cancer of prostate and urinary bladder) (Reste et al., 2012; Reste, 2013; 2014), that might be explained by excretion of incorporated radionuclides through kidneys and excessive irradiation of urogenital organs (Anonymous, 2001).

Thyroid cancer occurred 10.6 times more frequently in Chernobyl accident clean-up workers than in the rest of population (period from 1990 until 2000), and also at earlier age in CNPP clean-up workers (Kurjāne, 2001; Kurjane et al., 1999). CNPP recovery workers developed thyroid cancer most often at age 40-50, but for the general population at age 55-65 years. This clearly indicates that radiation was a dangerous risk factor for thyroid cancer after the Chernobyl nuclear accident (Kurjāne, 2001). In this study only data on thyroid cancer in men was used, since the thyroid cancer in women in Latvia is much more frequent $(8: 1)$.

The relative risk (RR) of cancer in 1996 was 33.27, and in 1997 increased to 42.64 (Kurjāne, 2001). The calculated cancer relative risk clearly indicates the danger of the 1986 nuclear accident to the health of those people who took part in the clean-up works. In further years, the morbidity of the thyroid cancer exhibited a tendency to decrease (RR 18.27 in 1998, and 9.42 in 1999). The peak morbidity of thyroid cancer was observed in 1992 in the population not exposed to irradiation (age group from 25 to 65 , which corresponds to age of Chernobyl accident clean-up workers). Later the morbidity tended to decrease, and, starting from 1995, the morbidity increased but with fluctuations (Kurjāne, 2001).
A similar trend in increasing morbidity of the thyroid cancer was observed not only in Latvia, but also in the rest of the world (Anonymous, 2006a; Yablokov et al., 2009).

Amongst the thyroid cancers of the Chernobyl accident clean-up workers from Latvia, the prevailing cancer was papillary adenocarcinoma (5/8 of clean-up workers having surgery). The characteristic morphological modifications of thyroid tissue in Chernobyl clean-up workers were follicle atrophy with epithelium sclerosis, which was more frequent than for other men of similar age having surgery during that period of time and who did not have occupational exposure to radiation (Kurjāne, 2001; Kurjāne et al., 2001).

Benign thyroid nodules were found three times more often in Chernobyl NPP accident clean-up workers during 1999 than in other men of similar age who did not have occupational exposure to ionising radiation (the control group) (Kurjāne, 2001).

\section{IMMUNOLOGICAL DISTURBANCES IN CHERNOBYL CLEAN-UP WORKERS}

Severe disorders of the immune system were observed among Chernobyl NPP accident clean-up workers from Latvia; characteristic late symptoms included leukocytosis, lymphopenia and malfunction of interferon (IFN) system (Kurjāne, 2001; Kurjane et al., 2001). The ability of peripheral blood lymphocytes (PBL) to produce IFNs has been found to be significantly decreased in $65-90 \%$ of accident clean-up workers and there was an increased level of circulating IFN in $40 \%$ of patients.

Compared to the control group, the Chernobyl NPP accident clean-up workers had significantly $(p<0.05)$ lower number of T-leukocytes (CD3+), T-helpers (CD4+), natural killer cells (CD16+) and B-cells (CD19+), higher IgA level and lower $\operatorname{IgG}$ concentration. In addition, decreased functional activity of the alternative (APH50) pathway of complement, an increased C3d concentration and depressed neutrophil phagocyte activity of neutrophil were found (Kurjāne, 2001; Kurjane et al., 2001).

Functional deficiency of the immune system of clean-up workers was observed during 1990-2005 (Bruvere et al., 1995; 2003; Kalnina et al., 2001; Kurjāne, 2001; Kurjane et al., 2001; Eglite et al., 2009). The CNPP clean-up workers were found to have a significantly lower proliferative ability of $\mathrm{T}$ and $\mathrm{B}$ lymphocytes and had elevated plasma concentrations of interleukin-6 (IL-6). Induction of TNF- $\alpha$ in the PBMC of clean-up workers was higher than that in healthy controls and this was correlated with age. Significant increases were also observed in the functions of the complement system as well as in levels of IL- 6 , TNF- $\alpha$ and SP-selectin. These observations suggest that the CNPP accident clean-up workers have a systemic chronic inflammatory process with possible accompanying dysfunction of major organs in period of over two decades following the accident (Kurjāne, 2001; Kurjane et al., 2001). 
CHANGE OF OXIDATIVE STRESS LEVEL 25 YEARS AFTER THE CHERNOBYL NPP DISASTER

During the work at the site CNPP clean-up workers were exposed not only to direct $\gamma$-radiation, but they inhaled toxic and radioactive isotopes, and volatile heavy metals derived from the reactor meltdown (Yablokov et al., 2009). These damaging factors produce different kinds of oxidative stress: radiation, chemical, psycho-emotional, and later inflammatory, pain and others. Radiation is known to reduce levels of antioxidants in body, thus causing greater risk for the organism (Halliwell and Gutteridge, 2007), since antioxidants are used for DNA repair, i.e. antioxidants remove free radicals that arise after exposure to radiation. It has been suggested that this reduction in different antioxidants may be responsible for increased levels of mutation (Halliwell and Gutteridge, 2007; Kumerova et al., 2000).

A study was started in 1998 as a long-term investigation on the role of changes in the antioxidant defence system in development of the post-radiation (post-Chernobyl) syndrome in clean-up workers from Latvia, who were involved in the recovery works following the Chernobyl NPP accident (Skesters et al., 2005; 2006a; 2006b; 2008; 2010). This was a randomised, double-blind, placebo-controlled, parallel group investigation involving 76 Chernobyl clean-up workers. The following parameters were determined: content of lipid-hydroperoxides, oxidisability and lipid peroxidation ratio in blood plasma, activity of glutathione peroxidase (GPx), catalase and concentration of $\mathrm{Cu}, \mathrm{Zn}$-Superoxide Dismutase (SOD), selenium (Se), zinc (Zn), and copper (Cu) (Skesters et al., 2005; 2006a; 2006b; 2008; 2010).

First results showed 5.5 times higher content of lipid peroxides and hydroperoxides, 3.5 higher blood plasma oxidisability, lipid peroxidation ratio, and concentration of TBARS products. Accordingly, activity of glutathione peroxidase in blood plasma was significantly decreased. Data showed that the level of selenium was very low $(46.0 \pm 7.8$ $\mu \mathrm{g} /$; the lowest Se concentration in the investigated groups was $17.0 \mu \mathrm{g} / \mathrm{L}$ ). $\mathrm{Zn}$ concentration in the serum of irradiated clean-up workers was higher by $50 \%$, and $\mathrm{Cu}$ concentration in blood was also elevated. All these data testify that there is high level of oxidative stress (Skesters et al., 2005; 2006a; 2006b; 2008; 2010).

Ten years later, the second stage results showed that concentration of Se in plasma had increased; intensity of lipid peroxidation, free radical production and content of TBARS product had decreased but remained quite high and nearly the first stage levels. Similarly, as before, concentrations of $\mathrm{Cu}$ and $\mathrm{Zn}$ remained unbalanced (Skesters et al., 2005; 2006a; 2006b; 2008; 2010). These data show that there is still a high level of oxidative stress, at a time even more than 20 years after direct contact with radioactive materials.

It is well known that oxidative stress provokes many different diseases and promotes development of some pathological conditions. It is clear that practically all of the diseases observed in medical examination were more or less are af- fected by oxidative stress. Some of these diseases are very strongly associated effect of oxidative stress (Barrow and Tanner, 1988; Halliwell and Gutteridge, 2007; Kumerova et al., 2000).

As mentioned above, most of the CNPP disaster clean-up workers from Latvia had progressive multiple illnesses that exhibited a tendency to progress; their morbidity exceeded that observed in the general Latvian male population. Most of these workers had up to 11 and more different illnesses. Chernobyl clean-up workers are characterised by significantly increased biological ageing processes of the body systems - neuroendocrine, gastrointestinal, cardiovascular, etc. Thus, they suffer from poly-symptomatic diseases almost in all body systems.

All these progressive changes in Chernobyl accident recovery workers' health as well as disturbances in functioning of immune system and increasing morbidity with oncological diseases confirms the evidence of prolonged systemic oxidant stress injury (Eglite et al., 2009; Skesters et al., 2010). Oxidative stress is imposed on cells as a result of one of three factors: 1) an increase in oxidant generation, 2) a decrease in antioxidant protection, or 3) a failure to repair oxidative damage. Cell damage is induced by reactive oxygen species (ROS). The main source of ROS in vivo is aerobic respiration, although ROS are also produced by peroxisomal $\beta$-oxidation of fatty acids, microsomal cytochrome $\mathrm{P}_{450}$ metabolism of xenobiotic compounds, and stimulation of phagocytosis by pathogens or lipopolysaccharides, arginine metabolism, and tissue specific enzymes. Under normal conditions, ROS are cleared from the cell by the action of SOD, catalase, or GPx. The main damage to cells results from the ROS-induced alteration of macromolecules such as polyunsaturated fatty acids in membrane lipids, essential proteins, and DNA. Additionally, oxidative stress and ROS have been implicated in diseases such as Alzheimer's disease, Parkinson's disease, cancer, and ageing (Sies, 1991; Yin and Chen, 2005; Halliwell and Gutteridge, 2007).

In general, regardless of observed improvement by increased antioxidative defence and decrease in some lipid peroxidation parameters, intensive long-term oxidative stress still remains as an important risk factor for CNPP clean-up workers (Skesters et al., 2005; 2006a; 2006b; 2008; 2010). Therefore, it is necessary to provide treatment to improve the antioxidative condition. For this purpose, some antioxidants and, possible, non-steroid anti-inflammatory drugs should be indicated for long-term application (Skesters et al., 2010).

\section{FUTURE DIRECTIONS AND RESEARCH NEEDS}

The research on victims of the Chernobyl accident in last 25 years has covered a broad spectrum of scientific directions, including epidemiological studies, biochemical and immunological studies, neurophysiological studies and many others. Nevertheless, changing morbidity structure of CNPP 
workers diseases and clinical manifestations show a need to continue studies on late effects of ionising radiation exposure. The importance of such studies is raised by other accidents in nuclear power plants with release of radioactive substances, which regularly occur in different parts of the globe. The latest accident in Japan in March 2011 in the Fukushima nuclear power plant was a clear demonstration of unsafety of nuclear power, which may have long-lasting consequences for inhabitants of the Earth.

Acute severe exposure to ionising radiation and chronic low dose exposure differ greatly. External high dose exposure was studied in great detail in victims of Hiroshima and $\mathrm{Na}$ gasaki bombings, as well as after other atom bomb tests. But knowledge on incorporated radionuclides biological effects in humans is insufficient. More studies are needed to reveal changes in molecular interaction inside the organism due to chronic exposure to ionising radiation. Studies are needed to identify chronic exposure to ionising radiation (e.g. incorporated radionuclides with long disintegration half-life) genetic effects not only in victims of Chernobyl accident, but also in their offspring.

The epidemiological studies on CNPP clean-up workers should be continued, as it is the main source of information on late effects in a large cohort. The epidemiological studies on progeny of CNPP clean-up workers are also necessary.

\section{REFERENCES}

Aleksanin, S. S. (2010). Regularity of somatic pathology formation in late period after Chernobyl NPP accident and experience of targeted health care of clean-up workers [Алексанин С. С. Закономерности формирования соматической патологии в отдаленном периоде после аварии на Чернобыльской АЭС и опыт оказания адресной медицинской помощи ликвидаторам последствий аварии]. Mediko-biologicheskiye problemi zhiznedeyatelnosti [Медико-биологические проблемы жизнедеятельности], 1 (3), 128-134 (in Russian).

Anonymous (2000). Report of the United Nations Scientific Committee on the Effects of Atomic Radiation to the General Assembly. The Chernobyl Accident, pp. 13-15. Available at:

http://www.unscear.org/unscear/en/publications/2000_1.html (accessed 17 May 2012).

Anonymous (2001). Ionizing Radiation, Part 2: Some Internally Deposited Radionuclides. In: IARC Monographs on the Evaluation of Carcinogenic Risks to Humans. Vol. 78. IARC Press (International Agency for Research on Cancer), Lyon, pp. 88-475.

Anonymous (2006a). Epidemiological evaluation of cardiovascular disease and other non-cancer diseases following radiation exposure. Report to the General Assembly, with Scientific Annexes. Vol. I, Annex B. United Nations, New York, pp. 327-375.

Anonymous (2006b). Health Risks from Exposure to Low Levels of Ionizing Radiation - BEIR VII Phase 2. The National Academies Press, Washington, D.C. 422 pp. (at pp. 313-323).

Anonymous (2006c). Health Effects of the Chernobyl Accident and Special Health Care Programmes. Report of the UN Chernobyl Forum, Expert Group "Health". Bennett, B., Repacholi, M., Carr, Z. (eds.). World Health Organization, Geneva. 167 pp. (at pp. 2-30).

Anonymous (2011). Sources and Effects of Ionizing Radiation. UNSCEAR 2008 Report to the General Assembly with Scientific Annexes. Radiation exposures in accidents. Health effects due to radiation from the Chernobyl accident. Effects of ionizing radiation on non-human biota. New York: United Nations, Vol. II, Annexes C, D, E. 221 pp.
Barrow, L., Tanner, M. S. (1988). Copper distribution among serum proteins in paediatric liver disorders and malignancies. Eur. J. Clin. Invest., 18 (6), $555-560$.

Bruvere, R., Heisele, O., Zvagule, T., Volrate, A., Duks, A., Churbakova, E. (1995). The immune state of Latvia's inhabitants involved in the Clean-up of high levels of radioactivity in Chernobyl. Acta Medica Baltica, 2 (1), 36-43.

Bruvere, R., Gabruseva, N., Volrate, A., Heisele, O., Feldmane, G., Zvagule, T., Balodis, V. (2003). Functional deficiency of the immune system of Chernobyl accident clean-up workers residing in Latvia. Proc. Latvian Acad. Sci., Section B, 57 (1/2), 17-21.

Churbakova, E., Dzerve, B., Eglite, M., Farbtuha, T., Zvagule, T. (1996). Health status and follow up of the Chernobyl nuclear power plant accident liquidators in Latvia. The radiological consequences of the Chernobyl accident. In: Proceedings of the $1^{\text {st }}$ International Conference on radiological consequences of the Chernobyl accident, 18-22 March 1996, Minsk, Belarus, pp. 929-934.

Churbakova, E., Farbtuha, T., Zvagule, T., Eglite, M., Jekabsone, I., Eglite, A. (1999). The health status of Chernobyl nuclear power plant accident liquidators from Latvia. Proc. Latvian Acad. Sci., Section B, 52, Supplement: Ecotoxicology Conference, 187-191.

Eglite, M., Churbakova, E., Farbtuha, T., Zvagule, T. (1997). Diseases of cardiovascular system of Chernobyl nuclear power plant station (NPS) accident clean-up workers in Latvia. Can. J. Cardiol., 13, Supplement B, 77.

Eglite, M. E., Zvagule, T. J., Rainsford, K. D., Reste, J. D., Čurbakova, E. V., Kurjane, N. N. (2009). Clinical aspects of the health disturbances in Chernobyl Nuclear Power Plant accident clean-up workers (liquidators) from Latvia. Inflammopharmacology, 17, 163-169.

Ginzburg, H. M., Reis, E. (1991). Consequences of the nuclear power plant accident at Chernobyl. Public Health Rep., 106 (1), 32-40.

Halliwell, B., Gutteridge, J. M. C. (2007). Free Radicals in Biology and Medicine. 4th edn. Oxford University Press, New York. 704 pp. (at pp. 53-60, 268-292).

Holodova, N. B., Zhavoronkova, L. A., Rizhov, B. N. (2012). Neurological, Neuropsychological and Neurophysiological Manifestations of Premature Aging among Chernobyl NPP Accident Clean-up Workers [Холодова Н. Б., Жаворонкова Л. А., Рыжов Б. Н. Неврологические, нейропсихологические и нейрофизиологические проявления преждевременного старения у участников ликвидации последствий аварии на Чернобыльской АЭС]. Mediko-biologicheskiye problemi zhiznedeyatelnosti [Медико-биологические проблемь жизнедеятельности], 1 (7), 112-120 (in Russian).

Kalnina, I., Gabruseva, N., Bruvere, R., Zvagule, T., Heisele, O., Volrate, A., Feldmane, G., Meirovics, I. (2001). Phenotypical characteristics of leukocytes membrane in Chernobyl clean-up workers from Latvia: use of the fluorescent probe ABM. Proc. Latvian Acad. Sci., Section B, 55 (1), 6-13.

Kalnina, I., Zvagule, T., Kirilova, E., Kurjane, N., Skesters, A., Silova, A., Gabruseva, N. (2012). Dynamics of lymphocyte membrane in Chernobyl clean-up workers with type 2 diabetes mellitus. J. Exp. Integr. Med., 2 (4), 357-363.

Kalnina, I., Kirilova, E., Zvagule, T., Kurjane, N., Skesters, A., Silova, A., Gabruseva, N., Gorbenko, G., Kirilov, G., Gonta, S. (2013). Radiationmodified albumin in type 2 diabetic patients. J. Exp. Integr. Med., 3 (1), 3-7.

Kalnina, I., Kirilova, E., Zvagule, T., Kurjane, N., Skesters, A., Silova, A., Gabruseva, N., Gorbenko, G., Kirilov, G., Gonta, S., Pimane, E. (2013a). Characteristics of albumin binding sites in patients and Chernobyl clean-up workers with type 2 diabetes mellitus. J. Exp. Integr. Med., 3 (3), 185-190.

Kumerova, A. O., Lece, A. G., Skesters, A. P., Orlikov, G. A., Seleznev, J. V., Rainsford, K. D. (2000). Antioxidant defence and trace element imbalance in patients with post radiation syndrome: First report on phase I studies. Biol. Trace Elem. Res., 77 (1), 1-12.

Kurjāne, N., Sočṇevs, A. (1999). Structure and functions of natural killer cells. Proc. Latvian Acad. Sci., Section B, 53 (6), 308-314. 
Kurjane, N., Groma, V., Orlikov, G., Ritenberga, R., Skudra, M., Lemane, R., Lemanis, A., Churbakova, E., Sochnev, A. (1999). Thyroid disorders in Chernobyl clean-up workers from Latvia. Proc. Latvian Acad. Sci., Section $B, 53$ (6), 315-321.

Kurjane, N., Farbtuha, T., Zvagule, T., Jaunalksne, I., Churbakova, E., Orlikovs, G., Sochnevs, A. (2000). Oncopathology in Chernobyl clean-up workers from Latvia: Epidemiological and immunological aspects. Збірник наукових праць Украінськой війсково-медичноі академіi [Proceedings on the Scientific Problems of Disaster Medicine and Emergency Medical Aid], Kiev, 7, 505-509.

Kurjāne, N. (2001). Černobiḷas avārijas seku likvidētāju klīniski imunologiskais pētījums 13 - 14 gadus pēc avārijas [Clinical Immunological Study of Chernobyl Accident clean-up workers 13-14 years after accident]. Doctoral dissertation, Rīga Stradiṇ̌ University, Rīga, Latvia (in Latvian). $132 \mathrm{pp}$

Kurjane, N., Bruvere, R., Shitova, O., Romanova, T., Jaunalksne, I., Kirschfink, M., Sochnevs, A. (2001). Analysis of the immune status in Latvian Chernobyl clean-up workers with nononcological thyroid diseases. Scand. J. Immunol., 54 (5), 528-533.

Mazarevica, G., Freivalds, T., Bruvere R., Gabruseva, N., Leice, A., Zvagule, T. (2000). Refractive properties of separate erythrocytes of Chernobyl clean-up workers at different $\mathrm{pH}$. Proceedings of SPIE (The International Society for Optical Engineering), 3921, 163-171.

Mironova, N., Eglite, M., Churbakova, E., Zvagule, T., Riekstina, D., Kärner, T. (1998). Electron spin resonance and instrumental neutron activation element analyses of Chernobyl nuclear power plant accident clean-up worker teeth. Proc. Latvian Acad. Sci., Section B 52, Supplement, 194-196.

Mironova-Ulmane, N., Pavlenko, A., Zvagule, T., Karner, T., Bruvere, R., Volrate, A. (2001a). Retrospective dosimetry for Latvian workers at Chernobyl. Radiat. Prot. Dosimetry, 96 (1-3), 237-240.

Mironova-Ulmane, N., Pavlenko, A., Zvagule, T., Kärner, T., Bruvere, R., Volrate, A. (2001b). Retrospective dosimetry for Latvian and clinical follow-up programme Chernobyl accident clean-up workers in Latvia. Proceedings of the European Workshop on Individual Monitoring of External Radiation, Radiation protection dosimetry, 26 (1-3), 237-240.

Nikiforov, A. M. (2002). Chernobyl NPP Accident Clean-up Workers' Pathology in Late Period [Никифоров А. М. Патология отдаленного периода у ликвидаторов последствий аварии на Чернобыльской АЭС]. БИНОМ, St-Petersburg, pp. 9-274 (in Russian).

Nyagu, A. I., Loganovsky, K. N. (1996). Mental disorders in the Chernobyl accident survivors. In: Revelling in Reference: $X$ World Congress of Psychiatry: Abstracts. (S-136-1), Madrid.

Petukhov, V. I., Dmitriev, E. V., Kalvinsh, I., Baumane, L. Kh., Reste, E. D., Zvagule, T., Skesters, A. P., Skalny, A. V. (2011). Metal-ligand homeostasis in epidermic cells of Chernobyl accident liquidators. Vitamins \& Minerals, 1 (2). Available at: http://www.omicsgroup.org/journals/metal-ligand-homeostasis-in-epidermic-cells-of-chernobyl-accidentliquidators-2167-0390.1000102.php?aid=4585 (accessed on 20 September 2016).

Reste, J. (2013). Jonizējošās radiācijas ilgstošai iedarbībai pakḷauto cilvēku novecošanas aspekti [The aging aspects of humans protractedly exposed to ionizing radiation]. Doctoral dissertation, Rīga Stradiņ̌̌ University, Rīga, Latvia (in Latvian) 211 pp.. Available at:

http://www.rsu.lv/petnieciba/promocija/promocijas-darbi (accessed 20 September 2016)

Reste, J. (2014). Jonizējošā starojuma ietekme uz cilvēku novecošanu. Ilgstošam apstarojumam paklauto cilvēku novecošanas aspekti [The impact of ionizing radiation on human aging. The aspects of aging in protractedly irradiated humans. Globe Edit, 2014 (in Latvian).

Reste, J., Kurjane, N., Zvagule, T., Eglite, M., Gabrusheva, N. (2012). Oncological morbidity pattern of Chernobyl accident workers from Latvia. In: International Proceedings of IFEH 12th World Congress on Environmental Health, Vilnius, Lithuania, 22-27 May 2012. Medimond, Bologna, pp. 105-109.
Reste, J., Zvigule, G., Zvagule, T., Kurjane, N., Eglite, M., Gabruseva, N., Berzina, D., Plonis, J., Miklasevics, E. (2014). Telomere length in Chernobyl accident recovery workers in the late period after the disaster. $J$. Radiat. Res., 55 (6), 1089-1100. Available at:

http://jrr.oxfordjournals.org/content/55/6/1089.full?sid=87a19384-bff04010-a97c-a65dfce32ab2 (accessed 20 September 2016).

Sies, H. (1991). Oxidative stress: From basic research to clinical application. Amer. J. Med., 91, 31S-8S

Silova, A. (2015). Oksidatīvā stresa rādītāju izmainas un korekcijas iespējas atsevišku patologiju gadījumos [Changes in oxidative stress parameters and its correction opportunities in particular pathologies]. Doctoral dissertation, Rīga Stradiňš University, Rīga, Latvia (in Latvian). Available at: http://www.rsu.lv/petnieciba/promocija/promocijas-darbi (accessed on 20 September 2016).

Skesters, A., Zvagule, T., Rainsford, K., Silova, A., Rusakova, N., Eglite, M., Callingham, B. (2005). Changes of selenium content in blood of clean-up worker patients after 14- and 19-years period of the nuclear reactor disaster in Chernobyl NPP. Proceedings of 5th International Symposium on Trace Elements in Human: New Perspectives, 13?15 October 2005, Athens, Greece, pp. 676-682.

Skesters, A., Rozentale, B., Voicehovska, J., Zvagule, T., Rainsford, K., Silova, A., Rusakova, N., Petuhovs, V., Ivanchenko, L. and Larmane, L. (2006). Fluorescence method for Selenium determination in the blood plasma of Bronchial asthma, Hepatitis C virus, HCV / HIV co-infection diseases and post-Chernobyl syndrome patients. Polish J. Environ. Studies, 15 (4A), 94-96.

Skesters, A., Zvagule, T., Silova, A., Rainsford, K., Rusakova, N., Burdukova, I., Callingham, B. (2006a). Selenium connection with antioxidants in blood of Chernobyl clean-up workers. Proceedings of $3 r d$ International Conference: Metals in the Environment, Vilnius, Lithuania, 26-29 April 2006, pp. 203-205.

Skesters, A., Zvagule, T., Silova, A., Mustafins, P., Rainsford, K., Rusakova, N., Burdukova, I., Callingham, B., Larmane, L. (2006b). Selenium and vitamine $\mathrm{E}$ in blood of Chernobyl clean-up workers - 20-years after nuclear accident. Proceedings of 23 Workshop Jena, Germany, 27 September 2006: Macro and Trace Elements (Mengen- und Spurenelemente), pp. $38-43$.

Skesters, A., Zvagule, T., Larmane, L., Rainsford, K., Silova, A., Rusakova, N., Mustafins, P. (2008). Effects of selenium alone and with antioksidants and Ibuprofen mixture in Chernobyl catastrophe clean-up workers at risk of developing cancer. Cell Biol. Toxicol., 24 (1), 31.

Skesters, A., Zvagule, T., Silova, A., Rusakova, N., Larmane, L., Reste, J., Eglite, M., Rainsford, K. D., Callingham, B. A., Bake, M. A., Lece, A. (2010). Biochemical observations relating to oxidant stress injury in Chernobyl clean-up workers ("liquidators") from Latvia. Inflammopharmacology, 18, 17-23.

Skesters, A., Zvagule, T., Silova, A., Larmane, L., Rusakova, N., Kurjane, N., Kirilov, A., Kalnina, I., Kirilov, G., Gabruseva, N. (2010). Antioxidant therapy and its stability on Chernobyl clean-up workers. Int. J. Low Radiat., 7 (5), 409 ?421.

Viel, J. F., Curbakova, E., Dzerve, B., Eglite, M., Zvagule, T., Vincent, C. (1997). Risk factors for long-term mental and psychosomatic distress in Latvian Chernobyl liquidators. Environ. Health Perspect., 105 (6), 1539-1544.

Vlasova-Rozanskaya, J. V. (2009). Features of Ischemic Heart Disease Course in Victims of Chernobyl NPP Accident [Власова-Розанская Е. В. Особенности течения ишемической болезни сердца у пострадавших в результате аварии на Чернобыльской АЭС]. Mediko-biologicheskiye problemi zhiznedeyatelnosti [Медико-биологические проблемы жизнедеятельности], 1, 82-89 (in Russian).

Yablokov, A. V., Nesterenko, V. B., Nesterenko, A. V. (2009) Chernobyl: Consequences of the catastrophe for people and the environment. Ann. N. Y. Acad. Sci., 1181, 32-217. 
Yin, D., Chen, K. (2005). The essential mechanisms of aging: Irreparable damage accumulation of biochemical side-reactions. Exp. Gerontol., 40 (6), 455-465

Zvagule, T., Bruvere, R., Gabruseva, N., Balodis, V., Feldmane, G. (2002). Health problems shown by clinical and immunological tests in Chernobyl clean-up workers during a 15-year period (1986-2000). Proc. Latvian Acad. Sci., Section B, 56, 248-253.

Zvagule, T., Kurpniece, I., Eglite, M., Teibe, U., Gabruseva, N., Bruvere, R. (2003). Electrophysiological characteristics of functional state of
Chernobyl accident clean-up worker's brain. Proceedings of the International Conference:, Clinical Neurosciences: Neurophysiology, Neurology, Neurosurgery, Ukraine, Crimea, Yalta-Gurzuff, June l-10 2003, pp. 24-26.

Zvagule, T. (2004). Veselības traucējumu dinamika Černobilas avārijas seku likvidētājiem vēlīnā periodā pēc darba piesārnotajā vide (1996-2001) [Dynamics of health disturbances of Chernobyl accident recovery workers in late period after work in contaminated environment (1996-2001)]. Doctoral dissertation, Rīga Stradinš University, Rīga, Latvia (in Latvian)

Received 2 November 2015

\section{PĒTĪJUMI PAR ČERNOBIḶAS AVĀRIJAS SEKU LIKVIDĒTĀJU NO LATVIJAS VESELĪBAS STĀVOKLI VĒLĪNĀ PERIODĀ PĒC KATASTROFAS}

Šis raksts apkopo galvenos pētījumu rezultātus par Černobiḷas atomelektrostacijas (ČAES) avārijas seku likvidētāju no Latvijas veselības stāvokli, kuri iegūti pēdējo divdesmit gadu laikā. Aptuveni 6000 Latvijas iedzīvotāju piedalījās ČAES avārijas seku likvidācijas darbos 1986.-1991. gadā. Atrašanās laikā Černobiḷā viṇi tika pakḷauti gan ārējam, gan iekšējam apstarojumam, bet pēc atgriešanās Latvijā dzīvoja ar radioaktīvām vielām salīdzinoši nepiesārnotā vidē. Divdesmit piecu gadu laikā pēc katastrofas ČAES avārijas seku likvidētāji izgāja rūpīgas regulāras medicīniskas apskates, tika veikti klīniskie pētījumi par viṇu veselību, un tas ḷāva uzkrāt vērtīgu informāciju par jonizējošā starojuma ietekmes vēlīniem efektiem. Šīs publikācijas mērkis ir apkopot galvenos faktus par ČAES avārijas seku likvidētāju no Latvijas veselības stāvokli, kas savākti rūpīgā apsekojumā 25 gadu garumā pēc katastrofas. Šis raksts atspoguḷo ČAES avārijas rezultātā radiācijas ietekmei pakḷauto personu Latvijas valsts reǵistra datus un dod ieskatu galvenajos veselības traucējumos, kuri tika konstatēti epidemioloǵiskajos, klīniskajos, biokīmiskajos, imunoloǵiskajos un fizioloǵiskajos pētījumos. Latvijas pētījumu dati vēlīnā periodā pēc avārijas liecina par to, ka jonizējošais starojums varētu izraisīt cilvēku priekšlaicīgas novecošanas un polimorbiditātes attīstību. 